\title{
Study on Teaching Korean in the Context of "Ideological and Political Education in Courses"
}

\author{
Gao Yanjun ${ }^{1, \text { a }}$ Gong Shuyan ${ }^{2, b^{*}}$ \\ ${ }^{1}$ School of Foreign Languages, Shandong Technology and Business University, Yantai, Shandong, China \\ ${ }^{2}$ Youth League Committee of Shandong Technology and Business University, Yantai, Shandong, China \\ a18563891570@163.com \\ b*2867475396@qq.com
}

\begin{abstract}
As the economic exchange and trading grow between China and South Korea in the $21^{\text {st }}$ century, educational exchange and collaborations between the two countries have flourished. Students who have pursued further study in South Korea and have been deeply affected by the Korean culture featured by parades, religions, adornment of sissies and Cinderella, often fail to develop correct legal and critical thinking, and their values are distorted. To solve this problem, Korean language teachers at universities should build on the characteristics of the major, carry out ideological and political education in their classes, elaborate on the history of Korean culture, improve the students' critical thinking and help develop students into talents who can undertake the mission of national rejuvenation of China in the new era.
\end{abstract}

Keywords: ideological and political education in classes, Korean, education research

\section{INTRODUCTION}

Since China and South Korea established diplomatic relations in 1992, especially since the start of the $21^{\text {st }}$ century, Korean enterprises have marched into the market in mainland China, the economic bonds between the two nations grew, and the Korean culture found their way into China as well. As the Korean enterprises extend their market and the Korean culture gains popularity, universities in China have offered the course of learning Korean, which have trained lots of students who can speak Korean and provided the job market with these talents. Conventional Korean language teaching focuses merely on training the students' language proficiency, but pays no attention to their ideological and political awareness. Compared with ideological and political education in English and Japanese teaching, studies on the ideological and political education in Korean language teaching are rare. On the National Conference on Ideological and Political Education in Higher Education Institutions, President Xi Jinping pointed out that "we need to take cultivation of morals and virtues of students as the core, and introduce ideological and political education into the teaching process to realize an all-round development for students, and hash out a new pattern for development of higher education." Therefore, in Korean language education, colleges should not only impart professional knowledge, but introduce ideological and political education into the class according to the features of the major. The purpose is to cultivate patriotic talents who have a global vision and can undertake the mission of national rejuvenation of China.

\section{CAUSES FOR INTRODUCING IDEOLOGICAL AND POLITICAL EDUCATION TO KOREAN COURSES IN COLLEGES}

Compared with the majors of conventional foreign languages, the Korean language major started later in China, but has gained rapid development. Languages, as the carrier of culture, reflect the group ideology, values and social norms. In terms of the students, students majoring in Korean have their own characteristics compared with students majoring in other languages, which makes the ideological and political education in Korean classes different from that in other classes. This can be seen from the following examples.

First, it has already been popular among students majoring in Korean to pursue further study in South Korea when they are still at university. Due to geographic proximity, relatively low tuition fees and favorable policies in Korea, many Chinese college students choose to go to Korea for half-year of one-year exchange programs, " $2+2$ " programs or pursuing master's degrees. In Shandong province, China, nearly all colleges that offer Korean 
language courses have exchange programs with universities in South Korea. As a result, students majoring in Korean are one of the largest groups going to Korea for further study in universities. Massive exchanges of students have led to a more robust exchange of culture. Yet, with the sudden shift of living conditions, students exposed to different ideologies in a foreign country will experience shocks to their values and patriotism.

Meanwhile, the fashion and entertainment culture of South Korea in these two decades has exerted deep impacts on the Chinese society and contemporary students. Dazzling songs and dances, charming fashion and inviting TV programs have greatly enriched people's life, but there are many students who take in all these without discerning the good from the bad. For instance, the popularity of fresh meat and sissy boys among male students and the indulgence of Cinderella's fairy tales among female students are closely connected to the TV culture imported from South Korea. The popularity of sissy boys has already stirred up a furore in China and has been the target of critics; the indulgence in Cinderella-style love stories among girls has been the result of the TV series about romance among the younger generation of financial magnates, in which playing the fool to angle for free lunch is a common practice. Fans of these TV series are likely to confuse the film plots with reality and grow money worship.

Moreover, Christianity prevails in South Korea, and the capital Seoul is renowned as "The Jerusalem of the East". In the middle of last century, about half of the 50 major religions around the world could find their followers in South Korea, and South Korea is now still the largest Christian country in the world. The church missionaries are enthusiastic and hospitable, and the churches are magnificent. Chinese students are the major targets of these churches. As a result, many Chinese students became Christians after coming back from South Korea. The Constitution of China has granted the people with the freedom to religious beliefs, but many students, due to limits in language proficiency and poor discernment, are likely to be drawn to churches unwittingly or out of curiosity. Without much knowledge about the doctrines and religious tenets, students are often manipulated by cults.

\section{PRACTICE OF INTRODUCING IDEOLOGICAL AND POLITICAL EDUCATION INTO KOREAN LANGUAGE CLASSES IN COLLEGES}

Given the aforementioned characteristics, it is urgent and important to introduce ideological and political education to Korean language classes. Many students majoring in Korean after coming back to China from abroad experience considerable shifts in thoughts, swaying between resolution and confusion. In this context, it is necessary to introduce ideological and political education into Korean classes, which is different from political and ideological classes; teachers need to combine teaching materials into the textbooks and courseware to introduce naturally the ideological and political education into the Korean classes. The practice of introducing political and ideological education to Korean classes in colleges has been analyzed from the following aspects.

\subsection{Paying attention to the difference in social contexts between China and South Korea}

Teachers of foreign languages, when teaching the students, need to relate to the social context and culture of the country, so do those teaching Korean. The teachers of Korean, like the learners of Korean, benefit from the SinoKorean exchange; most Korean teachers have studied in South Korea, so they have an in-depth understanding of the social context of South Korea, and teach the students by make comparison between these two countries. For example, students first to South Korea will be amazed by the freedom when seeing the election campaigns and demonstration parades on streets, and are likely to consider freedom an absolute and idealized right. In fact, freedom can be absolute or relative. Teachers should, from a dialectic perspective, interpret these two forms of freedom and the relationships between the self and the greater self in relation to the achievements that China has achieved in the battle against Covid-19. They should recognize the right to enjoy freedom, but meanwhile they should also be alert of the obsession with blind freedom.

\subsection{Exploring critical materials within the society of South Korea}

The prevalence of Korean culture in these decades has brought to China new ideas and knowledge. Knowing more about Korean entertainment culture can extend the college students' career, and update their thoughts. Now, boosted by the Internet and new media, the Korean fashion has presented new features and changes, and realized global spread of the entertainment industry and public culture. Yet, for the content and ideas of Korean fashion, we should take in them critically. For the dross in Korean culture, the humdrum criticism often fails to convince the students, so teachers should make use of the critical evidence from the local facts in South Korea. For example, the romance between the young generation of financial magnates in South Korea and ordinary girls in the Korean soup operas increases the female college students' obsession with the Cinderella-style love stories. This phenomenon has already been criticized by Korean people who insist that these soup operas are short of novelty and have adverse impacts on the growth of female adolescents. Also, Korean young heartthrobs have become idols that Chinese male college students try to mimic. The popularity of these young heartthrobs has been criticized in Korea as it reduces the masculinity of male students. In South Korea, however, men are required to enlist in the army for military service, so the young stars are often masculine enough despite their tender appearance. In China, however, most male college students 
only mimic what is outside and hence grow into sissy boys.

\subsection{Analyzing the popularity of Korean Christian culture in a rational way}

In the history of South Korea, Buddhism, witcheraft and Confucianism have been the major forms of religious beliefs. Under the intrusion of Japan, the nation has declined, and the traditional religions of South Korea also saw a downturn. As said by Karl Marx, "Religion is the sigh of the oppressed creature, the heart of a heartless world, and the soul of soulless conditions". Social unrest is the hotbed of religions. From 1910 to 1945 when South Korea was under the reign of Japan, the Christians took up this opportunity to publicize their national pride and culture, and led the Korean people towards western culture, trying to unite the western powers to fight against Japan. After WWII, the U.S. started to provide aid to South Korea, which made the destitute Korean admire the developed western powers. As a result, the Koreans who had already lost enthusiasm for their local religions began to embrace Christianity that embodied the western values and hinged on Christianity to rejuvenate their home country. As more and more students who have been in South Korea turned into Christians, teachers should, on the basis of encouraging religious freedom, guide the students to interpret the history of Christianity from the historical contexts of the Korean nation, analyze the deep causes for the prevalence of Christianity culture in South Korea so that the students can see religions rationally and do not go astray.

\subsection{Correctly understanding the national development law in a historical manner}

Going to South Korea for exchange programs marks the first journey of many college students. South Korea is a typical developed country, a member of OECD, with a GDP per capita reaching 30,000 dollars. The better life and the prevalence of Korean culture have led some students to blindly adorn Korean culture, and made them more likely to criticize the social injustice in China and made improper comments. The rise of South Korea is indispensable from the efforts of the Korean people, but also relies on the capital and technical support from Japan and the U.S. The case is rather different in China. After WWII, China was in penury and subject to the technical lockdown from the West, and has been under wars for about a hundred years, which cannot be matched by the South Korea. China has made great achievements by reform and opening-up for forty years completely on its own. For students who blindly worship the Korean culture, teachers should give lectures in light of facts, interpret the nation's development history based on the development law of countries, prevent the students from xenocentrism, promote patriotic education, and let them know that the rise of Japan and South Korea is just the preclude of the chapter of the great rejuvenation of China. For the defects of China's social system, teachers should admit the defects and the gap China has with other countries so as to encourage students to contribute to the development of China

\section{CONCLUSION}

Students majoring in Korean, due to convenience to pursue further study in South Korea, have been exposed to Korean culture at university, and studying Korean language and culture is beneficial to cultivating talents of a global vision. The shift of living conditions, however, is likely to cause shocks to the students studying abroad. College students whose mind and thoughts are developing often fail to see the essence from the appearance of facts. Therefore, teachers should make innovations in the teaching process, integrate ideological and political education into the teaching of major courses, which is an inevitable trend in teaching reforms. The ideological and political education is the foundation of college education as it improves the ideological and political awareness of students, and also make the teaching of Korean language more practical, intellectual and interesting. To introduce ideological and political education into the Korean language classes can help shape the students' world view, life outlook and values, and train them into talents who can undertake the mission of national rejuvenation of China in the new era.

\section{REFERENCES}

[1] Wang A. Y. Teaching of "Intensive Korean Reading" class promoted by the introduction of ideological and political education to classes. Modern Communication, 2019, 3: 35-36.

[2] Liu L. N. Ideas and methods to integrate ideological and political education to Korean classes in universities. Korean Teaching and Research, 2020, 2:73-78.

[3] Hu M. Y., Yang X. Y., Ye H. Y. Impacts of popularity of Korean culture on contemporary college students and countermeasures. Technology World, 2015 , $12: 127-128$.

[4] Shen Q., Lin S. D. Why Korean fashion gains popularity? Brand Research, 2016, 4:75-96.

[5] Huang K. History and current situation of Christianity in South Korea. Science and Atheism, 2008, 1:45-50.

[6] He Y. Y. Young Heartthrobs, Made in Korea! Xinmin Weekly, 2015, 28: 78 - 79 .

[7] Jin H. Y., Yu M. Y. Study on teaching design and application of "ideological and political education in courses" in the advanced Korean listening course. Korean Language in China, 2021, 2: 33-43.

[8] Jian H. Influence of Korean-wave screen culture on Chinese college students and countermeasures. Home Drama, 2021, 2: 141-142. 
[9] Tian L. Influence of Korean screen culture on values of Chinese college students. Journal of Hainan Normal University (Social Sciences), 2014, 3 (27): 107-110.

[10] Qiu D. M. Influence of Korean-wave culture on moral education of Chinese college students. Peony, 2017, 36: 118-120.

[11] Gao Y. Study on the influence of Korean strategies for building its national image on Chinese people. Journal of Luoyang Institute of Science and Technology (Social Sciences), 2016, 5 (36): 79-84.

[12] Zhang R. 2014. Study on Korean culture and diplomacy based on Korean Wave. Tianjin Normal University.

[13] Bai B. Study on Korean and Chinese exchange students. Business, 2014, 6: 217.
[14] Cui J. H. Study on how Korean and Chinese exchange students adapt to the school life. Journal of China Youth University for Political Sciences, 2012, 5 (31): 67-71.

[15] Liu Y. C. Motivation, characteristics and trend of Korean Christianity missionary movement in foreign countries. Journal of Jiangnan Social University, 2020, 4 (22): 68-75.

[16] Liu Y.B., Analysis of the drive for Korean modernization --- economic globalization and fastgrowing Korean economy. Journal of Shandong University (Philosophy and Social Sciences), 2003, 5: $98-101$.

[17] Pu S. Z. Building on transformation and upgrading, technology and economy. Management and Administration, 2015, 8: 8-9. 